\title{
FIVE LOAVES AND TWO FISHES: AN EMPIRICAL STUDY IN PSYCHOLOGICAL TYPE AND BIBLICAL HERMENEUTICS AMONG ANGLICAN PREACHERS
}

Author:

Leslie J. Francis ${ }^{1,2}$

\section{Affiliations:}

${ }^{1}$ Warwick Religions and Education Research Unit, University of Warwick, United Kingdom

${ }^{2}$ Faculty of Theology, University of Pretoria, South Africa

Correspondence to: Leslie Francis

email:

leslie.francis@warwick.ac.uk

\section{Postal address:}

Warwick Religions and Education Research Unit, Institute of Education, University of Warwick, Coventry CV4 7AL, United Kingdom

\section{Keywords:}

Bible; hermeneutics; psychological type; psychology; religion; SIFT

Dates:

Received: 15 Feb. 2010 Accepted: 23 Feb. 2010 Published: 12 Aug. 2010

How to cite this article: Francis, L.J., 2010, 'Five loaves and two fishes: An empirical study in psychological type and biblical hermeneutics among Anglican preachers', HTS Teologiese Studies/Theological Studies 66(1), Art. \#811, 5 pages. DOI: $10.4102 /$ hts.v66i1.811

This article is available at:

http:/ / www.hts.org.za

\section{Note:}

Prof. Dr L. Francis is participating as a research associate in the research project Biblical theology and hermeneutics, directed by Prof. Dr Andries G. van Aarde, Honorary Professor at the Faculty of Theology at the University of Pretoria, South Africa.

\section{(C) 2010. The Authors.} Licensee: OpenJournals Publishing. This work is licensed under the Creative Commons Attribution License.

\section{ABSTRACT}

The sensing, intuition, feeling and thinking (SIFT) method of biblical hermeneutics and liturgical preaching has its roots in three fields: a theology of individual differences situated within the doctrine of creation, an application of Jungian psychological-type theory and empirical observation. The present study tested the empirical foundations for this method by examining the psychological-type profile of two groups of Anglican preachers (24 licensed readers in England and 22 licensed clergy in Northern Ireland) and by examining the content of their preaching according to their dominant psychological-type preferences. These data provided further support for the psychological principles underpinning the SIFT method of biblical hermeneutics and liturgical preaching.

\section{INTRODUCTION}

The sensing, intuition, feeling and thinking (SIFT) method of biblical hermeneutics and liturgical preaching was developed and tested in a three-volume response to the Gospel readings proposed for the principal Sunday service by the Revised Common Lectionary (Francis \& Atkins 2000, 2001, 2002), grounded in the wider hermeneutical and homiletic debates by Francis and Village (2008) and displayed in a variety of contexts by Francis (1997, 2003, 2006a, 2006b, 2007). While a number of contextual approaches to hermeneutics has drawn on sociological categories (such as gender, oppression and ethnicity), the SIFT method draws on psychological categories grounded in a clear theology of individual differences and rooted in a classical Christian doctrine of creation.

Francis (2005) introduced his distinctive notion of the theology of individual differences by drawing on the rich implications of Genesis 1:27. According to that passage, both men and women are created in the image of God; it is the individual differences between men and women that reflect the divine image. Extrapolating from the importance of sex differences in understanding the divine image, Francis speculated about other key human individual differences that may, along with sex differences, be attributed to the divine intentionality (the doctrine of creation) rather than to the corruption of human sinfulness (the doctrine of fall). Such human individual differences, he argued, include ethnic differences and psychological-type differences.

The psychological-type theory has its origins in the pioneering and creative work of Carl Jung (e.g. Jung 1971) but has been developed, clarified and popularised through a range of psychologicalassessment devices, most notably the Myers-Briggs Type Indicator (Myers \& McCaulley 1985), the Keirsey Temperament Sorter (Keirsey \& Bates 1978) and the Francis Psychological Type Scales (Francis 2005), which have been applied within religious and theological contexts. As generally understood, there are four key components to the psychological-type theory and each of these four components can be experienced and expressed in two distinctive and opposing ways. The theory distinguishes between two orientations (introversion and extraversion), two perceiving functions (sensing and intuition), two judging functions (thinking and feeling) and two attitudes toward the outer world (judging and perceiving).

The two orientations are concerned with the source of personal energy and how and where it is focused. On the one hand, extraverts are orientated toward the outer world. They are energised by events and people around them; they enjoy communicating and thrive in stimulating and exciting environments. They tend to focus their attention on what is happening outside of themselves. They are usually open people, they are easy to get to know and they enjoy having many friends. On the other hand, introverts are orientated toward their inner world. They are energised by their inner ideas and concepts and they enjoy solitude, silence and contemplation, as they tend to focus their attention on what is happening in their inner life. They usually prefer a small circle of intimate friends rather than many acquaintances.

The two perceiving functions are concerned with the way in which people perceive information. Firstly, sensing types focus on the realities of a situation as perceived by the senses. They tend to concentrate on specific detail rather than on the overall picture. They are concerned with the actual, the real, the practical and they tend to be down to earth and matter of fact. Alternatively, intuitive types focus on the possibilities of a situation, perceiving meanings and relationships. They may feel that perception by the senses is not as valuable as information gained from the unconscious mind, as indirect associations and concepts impact on their perception. They focus on the overall picture rather than on specific facts and data.

The two judging functions are concerned with the criteria that people use to make decisions and judgements. On the one hand, thinking types make judgements based on objective, impersonal logic. They value integrity and justice. They are known for their truthfulness and for their desire for fairness. They consider conforming to principles to be of more importance than cultivating harmony. On the other hand, feeling types make judgements based on subjective, personal values. They value compassion and mercy. They are known for their tactfulness and for their desire for peace. They are more concerned with promoting harmony than adhering to abstract principles. 
The two attitudes toward the outer world are concerned with which of the two sets of functions (judging or perceiving) is preferred in dealings with the outer world. Judging types seek to order, rationalise and structure their outer world, as they actively judge external stimuli. They enjoy routine and established patterns. They prefer to follow schedules in order to reach established goals and may make use of lists, timetables and diaries. They tend to be punctual, organised and tidy. They prefer to make decisions quickly and to stick to their conclusions once made. Conversely, perceiving types do not seek to impose order on the outer world but are more reflective, perceptive and open, as they perceive external stimuli. They have a flexible, open-ended approach to life. They enjoy change and spontaneity. They prefer to leave projects open in order to adapt and improve them. Their behaviour may often seem impulsive and unplanned.

Jung's view is that each individual develops one of the perceiving functions (sensing or intuition) at the expense of the other and one of the judging functions (thinking or feeling) at the expense of the other. Moreover, for each individual, either the preferred perceiving function or the preferred judging function takes preference over the other, leading to the emergence of one dominant function, which shapes the individual's dominant approach to life. Dominant sensing shapes the practical person. Dominant intuition shapes the imaginative person. Dominant thinking shapes the analytical person. Dominant feeling shapes the humane person. According to Jungian-type theory, the function paired with the dominant function is known as the 'inferior function'. It is here that individuals experience the most difficulty: dominant sensers may struggle with intuition dominant intuitives may struggle with sensing, dominant feelers may struggle with thinking and dominant thinkers may struggle with feeling.

In essence, the SIFT method of biblical hermeneutics and liturgical preaching systematically applies the four sets of questions posed by the four psychological functions of sensing and intuition (the two perceiving functions) and of thinking and feeling (the two judging functions) to each passage of scripture. The two perceiving functions (sensing and intuition) are applied first, as the perceiving process is concerned with gathering information and ideas. This is the irrational process unconcerned with making judgements or with formulating evaluations. The two judging functions (thinking and feeling) are applied second, as the judging process is concerned with evaluating information and ideas. Both feeling and thinking are rational functions.

The first step in the SIFT method addresses the sensing perspective. It is the sensing perspective that gets to grip with a text itself, giving proper attention to the details of a passage, and that may wish to draw on the insights of the historical methods of biblical scholarship in order to draw in 'facts' from other parts of the Bible. The first set of questions asks, 'How does this passage speak to the sensing function? What are the facts and details? What is there to see, to hear, to touch, to smell and to taste?

The second step in the SIFT method is to address the intuitive perspective. It is the intuitive perspective that relates a biblical text to wider issues and concerns. The second set of questions asks, 'How does this passage speak to the intuitive function? What is there to speak to the imagination, to forge links with current situations and to illuminate issues in our lives?'

The third step in the SIFT method addresses the feeling perspective. It is the feeling perspective that examines the human interest in the biblical text and learns the lessons of God for harmonious and compassionate living. The third set of questions asks, 'How does this passage speak to the feeling function? What is there to speak about fundamental human values, about the relationships between people, and about what it is to be truly human?'

The fourth step in the SIFT method is to address the thinking perspective. It is the thinking perspective that examines the theological interest in the biblical text and that reflects rationally and critically on issues of principle. The fourth set of questions asks, 'How does this passage speak to the thinking function? What is there to speak to the mind, to challenge us on issues of truth and justice and to provoke profound theological thinking?'

Although the research method leading to the development of the SIFT method of biblical hermeneutics and liturgical preaching has been largely theoretically driven, there are four empirical studies that have examined this theoretical development.

In the first study, Bassett, Mathewson and Gailitis (1993) examined the link between the preferred interpretations of scripture and the psychological preferences established partly by the psychological-type theory and partly by a measure of problem-solving styles. Participants were asked to read four passages from New Testament epistles and then offered a choice of interpretations that were intended to express preferences for 'thinking' or for 'feeling' (as defined by the psychologicaltype theory) and preferences for 'collaborative', for 'deferring' or for 'independent' (as defined by this problem-solving typology). Although mixing two personality models makes the results difficult to interpret, the data provided some support for a link between psychological-type preference and choice of interpretation. Most obviously, those classed as feeling types showed a preference for feeling-type interpretations.

In the second study, Village and Francis (2005) invited a sample of 404 adult lay Anglicans from 11 different churches to read a healing story from Mark's Gospel and then to choose between parts of interpretative statements designed to distinguish between the perceiving functions (sensing and intuition) and between the judging functions (thinking and feeling). The participants also completed the Keirsey Temperament Sorter (Keirsey \& Bates 1978) as a measure of psychological type. The data demonstrated that, when forced to choose between contrasting options, the participants preferred interpretations that matched their psychological-type preferences in both the perceiving process and the judging process.

In the third study, Francis, Robbins and Village (2009) invited a sample of 389 experienced preachers to read Mark 1:29-39 and to record their evaluations of the four reflections on this passage proposed originally by Francis (1997), which were derived from the SIFT method. The participants also completed the 126-item Form G (Anglicised) of the Myers-Briggs Type Indicator (Myers \& McCaulley 1985) as a measure of psychological type. The data demonstrated that preachers were four times more likely to prefer a sensing interpretation of the text rather than a thinking interpretation, emphasising the richness of the narrative rather than facing the theological questions posed by it. Moreover, there was little evidence to suggest that preachers were less likely to appreciate interpretations consonant with their less-preferred function than those consonant with their most-preferred or dominant function. In this sense, the SIFT method should be accessible to preachers of all psychological types.

In the fourth study, Village (in press) invited a sample of 718 recently ordained Anglican clergy serving in England, Ireland, Scotland and Wales to read the healing story from Mark 9:1429 and to select between interpretative statements designed to appeal to particular psychological-type preferences. The participants also completed the Francis Psychological Type Scale (Francis 2005) as a measure of psychological type. The data demonstrated that, after controlling for differences in biblical conservatism, preferences for interpretation were significantly correlated with psychological-type function preferences in both the perceiving process and the judging process. These findings confirmed and expanded the findings from the earlier study among Anglican lay people reported by Village and Francis (2005)

This small body of empirical research exploring issues relevant to the SIFT method of biblical hermeneutics and liturgical preaching has been shaped by the quantitative tradition within empirical theology and now needs complementing by the qualitative tradition (Francis, Robbins \& Astley 2009). 
Against this background, the objective of the present study is to test the extent to which preachers naturally draw on their dominant-type preference when they are constructing sermons. In the previous study reported by Francis et al. (2009), the aim was to examine how preachers respond to sermons prepared by others. In the present study, however, the aim is to examine what preachers prepare for themselves. The context in which such research can be conducted is provided by the preaching workshops operated by the author. In the context of these workshops, assessment of psychological type is made and the participants are given the opportunity to work in a range of type-alike groups, including groups based on the four dominant types of sensing, intuition, feeling and thinking. This paper reports the findings from two such preaching workshops: one arranged for Anglican preachers in England and one arranged for Anglican preachers in Northern Ireland.

\section{METHOD}

\section{Procedure}

Participants were invited by their diocesan trainers to attend a day session between 10:30 and 15:30 led by the author on the theme of introducing the SIFT method of biblical hermeneutics and liturgical preaching. The morning session introduced the ideas underpinning the theology and the psychology of individual differences and workshop opportunities were provided to explore type theory. At 13:00, the participants were invited to complete the type sorter and then to break for lunch. The findings of the type sorter were used to allocate the participants to dominant-type groups. Between 14:00 and $14: 45$, the four dominant-type groups were asked to prepare a presentation on their approach to Mark 6:34-44 (see Box 1). It is these presentations that provide the source materials for the following analyses.

Psychological type was assessed by the 1995 edition of the Keirsey Temperament Sorter (Keirsey 1998). This instrument proposes 10 items to discriminate between introversion and extraversion and three sets of 20 items to distinguish between sensing and intuition, between thinking and feeling and between judging and perceiving. Following the advice of Francis, Robbins and Craig (2007), tied scores on the Keirsey Temperament Sorter were assigned to introversion, intuition, feeling and perceiving.

\section{RESULTS}

\section{Study one}

Study one was conducted among 24 Anglican readers serving in the Church of England ( 9 men and 15 women). The type profile presented in Table 1 demonstrates a balance between introversion (13) and extraversion (11) and between sensing (12) and intuition (12), but preferences for feeling (17) over thinking (7) and for judging (19) over perceiving (5). In terms of dominant

\section{BOX 1}

The text of Mark 6:34-44 (New International Version) analysed in this study using the sensing, intuition, feeling and thinking (SIFT) method

\footnotetext{
${ }^{34}$ When Jesus landed and saw a large crowd, he had compassion on them, because they were like sheep without a shepherd. So he began teaching them many things.

${ }^{35} \mathrm{By}$ this time it was late in the day, so his disciples came to him. 'This is a remote place,' they said, 'and it's already very late. ${ }^{36}$ Send the people away so they can go to the surrounding countryside and villages and buy themselves something to eat.'

${ }^{37}$ But he answered, 'You give them something to eat.' They said to him, 'That would take eight months of a man's wages! Are we to go and spend that much on bread and give it to them to eat?'

${ }^{38}$ 'How many loaves do you have?' he asked. 'Go and see.' When they found out, they said, 'Five - and two fish.'

${ }^{39}$ Then Jesus directed them to have all the people sit down in groups on the green grass. ${ }^{40}$ So they sat down in groups of hundreds and fifties. ${ }^{41}$ Taking the five loaves and the two fish and looking up to heaven, he gave thanks and broke the loaves. Then he gave them to his disciples to set before the people. He also divided the two fish among them all. ${ }^{42}$ They all ate and were satisfied, ${ }^{43}$ and the disciples picked up twelve basketfuls of broken pieces of bread and fish. ${ }^{44} \mathrm{Th}$ number of the men who had eaten was five thousand.
}

types, there were 10 dominant feelers, 6 dominant sensers, 6 dominant intuitives and 2 dominant thinkers.

\section{Sensing group}

The sensing group generated an organised and numbered list of points. Point one emphasised the need to start with the information given in the passage itself and with the experience of the disciples. Here was a group of men in need of rest, quiet and refreshment. This is why Jesus led them across the water. But their needs were frustrated, being overtaken by the needs of the crowd: their need for spiritual refreshment was displaced by the crowd's need for physical refreshment. The disciples felt frustrated about their inability to meet the needs of the crowd, until Jesus pointed out to them that they had all the resources that they required. The disciples assumed that everyone would need to find their own food, until Jesus asked them to see what they had at hand. For this group, the narrative raised questions about discipleship in contemporary life and about the needs of today for spiritual feeding: as disciples, we need feeding ourselves and we need to feed others; the physical resources that we have are of importance and are adequate for the task.

\section{Intuitive group}

The intuitive group generated a highly coloured mind map graphically displaying a range of unconnected ideas. The members of this group were fascinated by the use of numbers: 5000 people, 5 loaves, 12 baskets and groups of 100 and 50 people. They contrasted the themes of scarcity and abundance, linked with grace and eucharist and with order emerging from chaos. They identified themes of confusion, compassion, teaching and feeding. They drew attention to Jesus's assessment of the crowd being like sheep without a shepherd. They went beyond the Markan text to reflect on the boy, who, in another gospel, was responsible for bringing the loaves; this naturally led to a discussion of children and communion, which then quickly became their main point of interest.

\section{Feeling group}

The feeling group focused immediately on the range of human needs displayed and recognised in the narrative: Jesus, the disciples and the crowd all had different and competing needs. According to this group, the miracle of the loaves and fishes proclaimed how the Lord provides and meets the range of human needs; the passage also displayed how apparently limited resources can be used wisely to the benefit of others. We are, therefore, called to use our resources and our skills to the benefit of others.

\section{Thinking group}

The thinking group provided a crisp analysis of the major themes in the passage, contrasting the approaches of Jesus and of the disciples. The disciples ran to Jesus in panic; Jesus remained calm. The disciples saw the negative side of the situation and saw no solution; Jesus saw the positive side of the situation and saw a way forward. The disciples identified the problem but not the solution; Jesus sent the disciples off to do further research. According to this group, Jesus offers a solution to human hunger by breaking bread, which points to his suffering and crucifixion; as disciples, we are offered this model to follow.

\section{Study two}

Study two was conducted among 22 Anglican clergy serving in the Church of Ireland (17 men and 5 women). The type profile presented in Table 2 demonstrates preferences for extraversion (13) over introversion (9), for sensing (18) over intuition (4), for feeling (16) over thinking (6) and for judging (21) over perceiving (1). In terms of dominant types, there were 9 dominant feelers, 8 dominant sensers, 3 dominant thinkers and 2 dominant intuitives.

\section{Sensing group}

The sensing group began by seeing the disciples as showing their own predisposition for sensing. The disciples, having conducted 
TABLE 1

Study 1: Anglican readers

\begin{tabular}{|c|c|c|c|c|c|c|}
\hline \multicolumn{4}{|c|}{ The Sixteen Complete Types } & \multicolumn{3}{|c|}{ Dichotomous Preferences } \\
\hline ISTJ & ISFJ & INFJ & INTJ & $E$ & 11 & $(45.8 \%)$ \\
\hline$n=2$ & $n=3$ & $n=3$ & $n=2$ & I & 13 & $(54.2 \%)$ \\
\hline$(8.3 \%)$ & $(12.5 \%)$ & $(12.5 \%)$ & $(8.3 \%)$ & & & \\
\hline+++++ & +++++ & +++++ & +++++ & S & 12 & $(50.0 \%)$ \\
\hline \multirow[t]{5}{*}{+++} & +++++ & +++++ & +++ & $\mathrm{N}$ & 12 & $(50.0 \%)$ \\
\hline & +++ & +++ & & & & \\
\hline & & & & $\mathrm{T}$ & 7 & $(29.2 \%)$ \\
\hline & & & & $\mathrm{F}$ & 17 & $(70.8 \%)$ \\
\hline & & & & $\mathrm{J}$ & 19 & $(79.2 \%)$ \\
\hline
\end{tabular}

\begin{tabular}{|c|c|c|c|c|c|c|}
\hline ISTP & ISFP & INFP & INTP & \multirow{2}{*}{\multicolumn{3}{|c|}{ Pairs and Temperaments }} \\
\hline$n=0$ & $n=3$ & $n=0$ & $n=0$ & & & \\
\hline \multirow[t]{8}{*}{$(0.0 \%)$} & $(0.0 \%)$ & (12.5\%) & $(0.0 \%)$ & & & \\
\hline & & +++++ & & IJ & 10 & (41.7\%) \\
\hline & & +++++ & & IP & 3 & $(12.5 \%)$ \\
\hline & & +++ & & EP & 2 & $(8.3 \%)$ \\
\hline & & & & EJ & 9 & (37.5\%) \\
\hline & & & & ST & 4 & $(16.7 \%)$ \\
\hline & & & & SF & 8 & $(33.3 \%)$ \\
\hline & & & & NF & 9 & $(37.5 \%)$ \\
\hline ESTP & ESFP & ENFP & ENTP & NT & 3 & $(12.5 \%)$ \\
\hline$n=0$ & $n=1$ & $n=0$ & $n=1$ & & & \\
\hline \multirow[t]{7}{*}{$(0.0 \%)$} & $(4.2 \%)$ & $(0.0 \%)$ & $(4.2 \%)$ & SJ & 11 & $(45.8 \%)$ \\
\hline & ++++ & & +++ & SP & 1 & $(4.2 \%)$ \\
\hline & & & & $\mathrm{NP}$ & 4 & $(16.7 \%)$ \\
\hline & & & & NJ & 8 & $(33.3 \%)$ \\
\hline & & & & TJ & 6 & $(25.0 \%)$ \\
\hline & & & & TP & 1 & $(4.2 \%)$ \\
\hline & & & & FP & 4 & $(16.7 \%)$ \\
\hline ESTJ & ESFJ & ENFJ & ENTJ & FJ & 13 & $(54.2 \%)$ \\
\hline$n=2$ & $n=4$ & $n=3$ & $n=0$ & & & \\
\hline$(8.3 \%)$ & $(16.7 \%)$ & $(12.5 \%)$ & $(0.0 \%)$ & IN & 8 & $(33.3 \%)$ \\
\hline++++ & ++++ & +++++ & & EN & 4 & $(16.7 \%)$ \\
\hline \multirow[t]{7}{*}{+++} & +++++ & +++++ & & IS & 5 & $(20.8 \%)$ \\
\hline & +++++ & ++ & & ES & 7 & $(29.2 \%)$ \\
\hline & ++ & & & & & \\
\hline & & & & ET & 3 & $(12.5 \%)$ \\
\hline & & & & $\mathrm{EF}$ & 8 & $(33.3 \%)$ \\
\hline & & & & IF & 9 & $(37.5 \%)$ \\
\hline & & & & IT & 4 & $(16.7 \%)$ \\
\hline
\end{tabular}

\begin{tabular}{|c|c|c|c|c|c|c|c|c|c|}
\hline \multicolumn{3}{|c|}{ Jungian Types (E) } & \multicolumn{3}{|c|}{ Jungian Types (I) } & \multicolumn{3}{|c|}{ Dominant Types } & \multirow{2}{*}{ 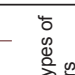 } \\
\hline & $n$ & $\%$ & & $n$ & $\%$ & & $n$ & $\%$ & \\
\hline E-TJ & 2 & 8.3 & I-TP & 0 & 0 & Dt. T & 2 & 8.3 & \\
\hline E-FJ & 7 & 29.2 & I-FP & 3 & 12.5 & Dt. F & 10 & 41.7 & \\
\hline ES-P & 1 & 4.2 & IS-J & 5 & 20.8 & Dt. S & 6 & 25 & 造 $\frac{8}{0}$ \\
\hline EN-P & 1 & 4.2 & IN-J & 5 & 20.8 & Dt. N & 6 & 25 & 了क乐 \\
\hline
\end{tabular}

$N=24 ;+=1 \%$ of $N$

a very thorough analysis of the situation, clearly saw the practical problem with which they were confronted: they were in a remote place, it was getting late and there was no ready supply of food. The disciples were practical and recognised that it would take the people some time to find the food that they needed; they also recognised that it would cost them eight months' wages to purchase enough food themselves. The disciples were therefore able to delineate the problem but they needed Jesus to provide the vision of a way forward. The members of the sensing group were fascinated by the details of the narrative. They counted the five loaves and the two fishes but, most of all, they counted the 12 baskets: the 12 baskets were a clear statement of plenty and a clear indication of the resource that God provides for the people. This group captured the overall message and theme of the passage as indicative of the practical concern of Jesus for the needs of the people.

\section{Intuitive group}

The intuitive group (of just two people) identified the Lord's Prayer as the lens through which to view the passage. The Lord's Prayer prays, 'Give us this day our daily bread.' Here is a petition full of meaning to a crowd that was hungry and without resources. But the hunger that matters is so much more than physical hunger. The passage showed God's amazing provision to offer the food that really matters. The passage also showed that God needs our collaboration in feeding the deep hunger of people. In faith, we need to take what is available and, within the Kingdom of God (for which we also pray in the Lord's Prayer), what is available by God's grace meets the needs and satisfies the hunger of all people. Seeing this passage through the lens of the Lord's Prayer also calls to mind the way in which John's Gospel used this passage as a springboard for teaching about Jesus as the Bread of Life. The Lord's Prayer is a live example of how God's will is done, bringing the Bread of Life to all.

\section{Feeling group}

The feeling group focused on the theme of compassion introduced at the beginning of the passage when Jesus saw the crowd and had compassion for them. Jesus showed great powers of empathy in putting himself in the shoes of the crowd, in experiencing how things felt for them and in sensing their quest for leadership and teaching. As a shepherd, Jesus felt for the people as his sheep. As a shepherd, Jesus wanted to take them into his care. As a shepherd, Jesus wanted to feed them. As a shepherd, Jesus had concern for them. It was with compassion that Jesus took the five loaves. It was with compassion that Jesus's action of sharing the bread demonstrated the love of God in action. It was with compassion that Jesus got the crowd seated in orderly groups on the green grass to prevent chaos from breaking out and to pre-empt any unruly scrabble for the food. This group also tried to see things through the eyes of the disciples: the disciples must have felt helpless at being unable to respond to Jesus's command to feed the crowd; they must have felt frustrated at being challenged to do the impossible. Indeed, Jesus's treatment of the disciples seemed insensitive and even unkind.

\section{Thinking group}

The thinking group identified four main themes of theological interest in the passage. The first theme concerned the location of the passage within the structure of Mark's Gospel. At this point of the Gospel, the Messianic Secret was still paramount: the disciples did not know who Jesus really was; Jesus was still teaching the disciples and preparing them for the insight proclaimed by Peter at Caesarea Philippi. The second theme concerned the connection between this feeding of the 5000 and the eucharist; particular attention was drawn to the fourfold eucharistic actions when Jesus took the five loaves, when Jesus gave thanks, when Jesus broke the loaves and when Jesus gave the fragments to the disciples to distribute to the people. The third theme concerned the sexism inherent in Mark's worldview: the passage explicitly referred to the number of men who had eaten and it remained for another of the Gospels to add a gloss regarding the women and children. The fourth theme concerned the Gospel imperative against waste and the care taken by the disciples to pick up all that remained of the broken pieces of bread and fish.

\section{CONCLUSION}

Building on quantitative studies reported by Bassett et al. (1993), Village and Francis (2005) and Francis et al. (2009), the present study employed a qualitative methodology to test the extent to which preachers (left to their own devices) preach in the voice shaped by their dominant psychological type. Data were provided by two groups of preachers who were participating in continuing professional educational workshops (24 licensed readers and 22 licensed clergy). These data demonstrated that, when working in type-alike groups, preachers generated preaching material consistent with the emphases of their dominant psychological type. Sensers gave close attention to the 
TABLE 2

Study 2: Anglican Clergy

\begin{tabular}{llllccc}
\hline \multicolumn{3}{l}{ The Sixteen Complete Types } & \multicolumn{5}{c}{ Dichotomous Preferences } \\
\hline ISTJ & ISFJ & INFJ & INTJ & E & 13 & $(59.1 \%)$ \\
$n=3$ & $n=5$ & $n=1$ & $n=0$ & I & 9 & $(40.9 \%)$ \\
$(13.6 \%)$ & $(22.7 \%)$ & $(4.5 \%)$ & $(0.0 \%)$ & & & \\
+++++ & +++++ & +++++ & ++++ & S & 18 & $(81.8 \%)$ \\
+++++ & +++++ & & & N & 4 & $(18.2 \%)$ \\
++++ & +++++ & & & & & \\
& +++++ & & & T & 6 & $(27.3 \%)$ \\
& +++ & & & F & 16 & $(72.7 \%)$ \\
& & & & & & \\
& & & & J & 21 & $(95.5 \%)$ \\
& & & & P & 1 & $(4.5 \%)$
\end{tabular}

$\begin{array}{llll}\text { ISTP } & \text { ISFP } & \text { INFP } & \text { INTP } \\ \boldsymbol{n}=\boldsymbol{0} & \boldsymbol{n}=\boldsymbol{0} & \boldsymbol{n}=\boldsymbol{0} & \boldsymbol{n}=\boldsymbol{0} \\ (0.0 \%) & (0.0 \%) & (0.0 \%) & (0.0 \%)\end{array}$

Pairs and Temperaments

IJ $9 \quad(40.9 \%)$

IP $0 \quad(0.0 \%)$

EP $1 \quad(4.5 \%)$

EJ $12(54.5 \%)$

ST $6 \quad(27.3 \%)$

SF $12 \quad(54.5 \%)$

NF $4 \quad(18.2 \%)$

$\begin{array}{lllll}\text { ESTP ESFP ENFP ENTP NT } & 0 & (0.0 \%)\end{array}$

$\begin{array}{lllllll}n=0 & n=0 & n=1 & n=0 & & & \\ (0.0 \%) & (0.0 \%) & (4.5 \%) & (0.0 \%) & \text { SJ } & 18 & (81.8 \%)\end{array}$

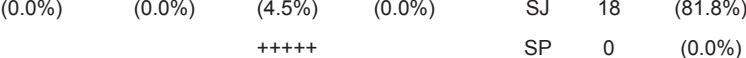

NP $1 \quad(4.5 \%)$

NJ $3 \quad(13.6 \%)$

TJ $6 \quad(27.3 \%)$

TP $0 \quad(0.0 \%)$

FP 1 (4.5\%)

$\begin{array}{llllll}\text { ESTJ ESFJ } & \text { ENFJ } & \text { ENTJ } & \text { FJ } & 15 & (68.2 \%)\end{array}$

$\begin{array}{lllllll}n=3 & n=7 & n=2 & n=0 & & & \\ (13.6 \%) & (31.8 \%) & (9.1 \%) & (0.0 \%) & \text { IN } & 1 & (4.5 \%)\end{array}$

$\begin{array}{lllll}+++++ & +++++ & \text { EN } & 3 & (13.6 \%)\end{array}$

+++++ + +++++ $++\quad$ IS 8 (36.4\%)

$\begin{array}{lllll}++++ & \text { ES } & 10 & (45.5 \%)\end{array}$

$\begin{array}{lll}+++++ & \text { ET } 3 & (13.6 \%)\end{array}$

EF $10 \quad(45.5 \%)$

$++\quad$ IF $\quad 6 \quad(27.3 \%)$

IT $3 \quad(13.6 \%)$

\begin{tabular}{|c|c|c|c|c|c|c|c|c|c|}
\hline \multicolumn{3}{|c|}{ Jungian Types (E) } & \multicolumn{3}{|c|}{ Jungian Types (I) } & \multicolumn{3}{|c|}{ Dominant Types } & \multirow{2}{*}{$\begin{array}{l}\text { "̄ } \\
\varnothing \\
0 \\
0\end{array}$} \\
\hline & $n$ & $\%$ & & $n$ & $\%$ & & $n$ & $\%$ & \\
\hline E-TJ & 3 & 13.6 & I-TP & 0 & 0.0 & Dt. T & 3 & 13.6 & ते 항 \\
\hline E-FJ & 9 & 40.9 & I-FP & 0 & 0.0 & Dt. F & 9 & 40.9 & $\frac{n}{0} \div \frac{0}{0}$ \\
\hline ES-P & 0 & 0.0 & IS-J & 8 & 36.4 & Dt. S & 8 & 36.4 & 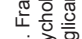 \\
\hline EN-P & 1 & 4.5 & IN-J & 1 & 4.5 & Dt. N & 2 & 9.1 & 广记定 \\
\hline
\end{tabular}

details of the text and focused on practical outcomes. Intuitives allowed the text to spark their imagination and sometimes ended up with themes far removed from the starting point of the passage itself. Feelers saw the passage through the lens of compassionate concern and from the perspective of the people within the narrative. Thinkers saw the passage from the perspective of the ongoing theological issues raised.

Overall, these data suggest that, if preachers are to access and proclaim the four distinctive voices of the hermeneutical process advocated by the SIFT method, it is important for them to be trained to approach scripture through their less-preferred psychological-type functions as well as through their dominant function. Experience-based workshops, such as those employed in the present study, provide an efficient and effective method for implementing this kind of practical training.

The two main limitations of the present study were, firstly, that only one passage of scripture was employed and, secondly, that only two groups of preachers were involved in the research. These two limitations need to be addressed by further replication studies capable of extending the range of scripture employed and capable of working with other groups of preachers. The present study suggests that further research of this nature is likely to illustrate more fully the link between psychologicaltype preferences and hermeneutical approaches.

\section{REFERENCES}

Bassett, R.L., Mathewson, K. \& Gailitis, A., 1993, 'Recognising the person in biblical interpretation: An empirical study', Journal of Psychology and Christianity 12, 38-46.

Francis, L.J., 1997, Personality type and scripture: Exploring Mark's gospel, Mowbray, London.

Francis, L.J., 2003, 'Psychological type and biblical hermeneutics: The SIFT method of preaching', Rural Theology 1, 13-23.

Francis, L.J., 2005, Faith and psychology: Personality, religion and the individual, Darton, Longman and Todd, London.

Francis, L.J., 2006a, 'Mark and psychological type' in J. Vincent (ed.), Mark Gospel of action: Personal and community responses, pp. 98-108, SPCK, London.

Francis, L.J., 2006b, 'Psychological type and liturgical preaching: The SIFT method', Liturgy 21(3), 11-20.

Francis, L.J., 2007, 'Psychological types', in F. Watts (ed.), Jesus and psychology, pp. 137-154, Darton, Longman and Todd, London.

Francis, L.J. \& Atkins, P., 2000, Exploring Luke's Gospel: A guide to the gospel readings in the Revised Common Lectionary, Mowbray, London.

Francis, L.J. \& Atkins, P., 2001, Exploring Matthew's Gospel: A guide to the gospel readings in the Revised Common Lectionary, Mowbray, London.

Francis, L.J. \& Atkins, P., 2002, Exploring Mark's Gospel: An aid for readers and preachers using year $B$ of the Revised Common Lectionary, Continuum, London.

Francis, L.J., Robbins, M. \& Astley, J. (eds.), 2009, Empirical theology in texts and tables: Qualitative, quantitative and comparative perspectives, Brill, Leiden.

Francis, L.J., Robbins, M. \& Craig, C.L., 2007, 'Two different operationalisations of psychological type: Comparing the Myers-Briggs Type Indicator and the Keirsey Temperament Sorter', in R.A. Degregovia (ed.), New developments in psychological testing, pp. 119-138, Nova Science Publishers Inc., New York.

Francis, L.J., Robbins, M. \& Village, A., 2009, 'Psychological type and the pulpit: An empirical enquiry concerning preachers and the sift method of biblical hermeneutics', HTS Teologiese Studies/Theological Studies 65(1), 1-7.

Francis, L.J. \& Village, A., 2008, Preaching with all our soul, Continuum, London.

Jung, C.G., 1971, Psychological types: The collected works, vol. 6, Routledge and Kegan Paul, London.

Keirsey, D., 1998, Please understand me: 2, Prometheus Nemesis, Del Mar.

Keirsey, D. \& Bates, M., 1978, Please understand me, Prometheus Nemesis, Del Mar.

Myers, I.B. \& McCaulley, M.H., 1985, Manual: A guide to the development and use of the Myers-Briggs Type Indicator, Consulting Psychologists Press, Palo Alto.

Village, A., (in press), 'Psychological type and biblical interpretation among Anglican clergy in the UK', Journal of Empirical Theology.

Village, A. \& Francis, L.J., 2005, 'The relationship of psychological type preferences to biblical interpretation', Journal of Empirical Theology 18(1), 74-89. 